
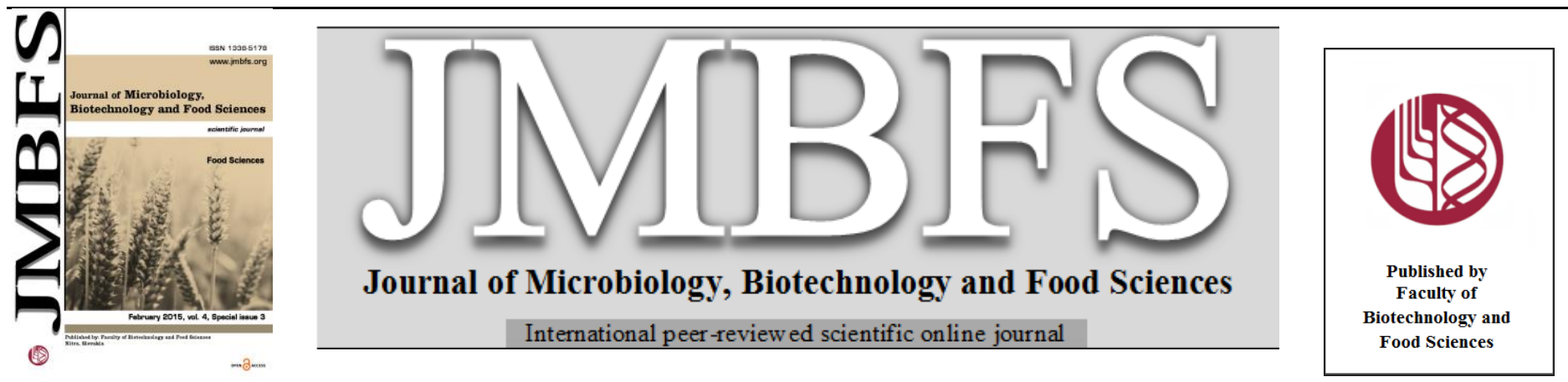

\title{
HEALTH BENEFITS OF KVASS MANUFACTURED FROM RYE WHOLEMEAL BREAD
}

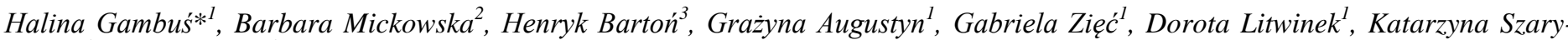 Sworst ${ }^{l}$, Wiktor Berski ${ }^{1}$}

Address(es): Professor Halina Gambuś, PhD.

${ }^{1}$ University of Agriculture in Krakow, Faculty of Food Technology, Department of Carbohydrate Technology, Balicka Street 122, 30-149 Krakow. Tel: +481266247 47.

${ }^{2}$ University of Agriculture in Krakow, Faculty of Food Technology, Malopolska Centre of Food Monitoring, Balicka 122, 30-149 Krakow.

${ }^{3}$ Medical College, Jagiellonian University, Faculty of Pharmacy, Department of Bromatology, Medical Street 9, 30-699 Krakow.

*Corresponding author:rrhgambu@cyf-kr.edu.pl

doi: 10.15414/jmbfs.2015.4.special3.34-39

\section{ARTICLE INFO}

Received 20.11.2014

Revised 1. 12. 2014

Accepted 2. 12. 2014

Published 2. 2. 2015

Regular article open $\bigodot_{\text {ACCESS }}$

\begin{abstract}
Kvass based on traditional technology completely disappeared from polish market. It was replaced by drinks, prepared from malt concentrates, wrongly named kvass. The aim of this study was therefore to obtain traditional bread kvass (by fermentation), using the mash prepared from commercial wholemeal rye bread, produced by 5-phase dough fermentation method, and to determine the quality of this kvass in terms of consumer acceptance, chemical composition and antioxidant activity. It has been demonstrated that based on the traditional wholemeal rye bread, it is possible to produce good quality bread kvass, with similar organoleptic qualities to the commercial kvasses, which contain several added flavours and preservatives. Natural bread kvass can be consumed by consumers of all ages, since it contains only trace amounts of alcohol, and it has almost double the dietary fibre content and three times lower content of reducing sugars as compared to the commercial kvasses. Laboratory made kvasses by natural fermentation also showed an increase in antioxidant activity by $60 \%$, when compared to commercial kvasses.
\end{abstract}

Keywords: Bread kvass, consumer acceptance, antioxidant activity, chemical composition

\section{INTRODUCTION}

Due to the growing nutritional awareness of consumers and growing interest in healthy organic and functional food, the producers are looking for new products targeted at this group of customers.

Kvass made from natural unmodified products, according to the traditional technology with implementation of modern biotechnological methods, is the product that meets the listed above requirements of food groups (Dziugan, 2006 a).

Currently, kvass based on the traditional production technology, has almost completely disappeared from polish market, while there are drinks, totally inadequate named kvass to the actual contents of the bottle. They are based on malt concentrate, as well as numerous additives. In addition, they contain an exceptional amount of preservatives. These concentrates are obtained by concentration of the wort, made from malted rye and barley and flour, up to $70 \%$. The use of a concentrate for the production of kvass greatly facilitates this process, by providing its shelf stability, repeatability and production uniformity. But in such kvass the caramel flavour with noticeable bitterness remains. The quality of such drink, wrongly called kvass, completely disqualifies this product (Dziugan, 2008).

Traditional production of kvass is based on the use of crackers made from wholemeal bread as raw material, as well as such additives as: raisins, lemons, cranberries, essential oils, etc (Dziugan, 2008)

The fermentation process is the most important step in the production of kvass, where the characteristic features of a beverage associated with the development of micro-organisms are shaped. Microbial conversion of sugar to lactic acid is done by lactic acid bacteria. The combined lactic - ethanol fermentation, during production of kvass, is however more complicated, due to the development of two physiological groups of microorganisms: bacteria and yeast, remaining in a symbiotic coexistence, which favours the development of unique flavour and aroma of the product (Dziugan, 2006 b).
The production of true kvass from rye bread mash, can be started in breweries, wineries and bottling carbonated water and drinks enterprises, but an argument against adoption of such production is an occurrence of a lactic - ethanol fermentation. Lactic acid bacteria and baker's yeast are an obvious threat to the basic microbiological production of this type of enterprises. Therefore, no brewery and no beverage producing company decided to take a risk of traditional kvass production. Keeping this fact in mind, its production can be run in small, local businesses such as bakeries (Dziugan, 2008).

Kvass should be honey - brown colour and sometimes precipitate, composed of yeast, is formed at the bottom. There is no need to filter kvass, because the yeast gives it a distinctive taste, and sediment disappears after shaking the liquid. Kvass foams, because it is naturally carbonated. The aroma of kvass is close to that of bread. The taste is sweet - bitter, and it is, more or less seasoned, determined by the time and temperature of fermentation. Kvass is the best tasting when chilled (Dziugan, 2006 a, b; Czerwińska, 2008).

Kvass is a soft drink, providing only low energy approximately $32 \mathrm{kcal} / 100 \mathrm{~g}$ (i.e. approx. 240-320 kcal / 1). It is a rich source of B vitamins, including thiamine $\left(\mathrm{B}_{1}\right)$, niacin $(\mathrm{PP})$, riboflavin $\left(B_{2}\right)$ and pyridoxine $\left(B_{6}\right)$. There is also a lot of folate, because yeasts - e.g. Saccharomyces cerevisiae, Candida milleri, Torulaspora delbrueckii are able to produce it. This drink has a positive effect on metabolism, and at the same time eliminates flatulence, hyperacidity and other digestive disorders (Czerwińska, 2008).

As a product of lactic - alcohol fermentation it does not require a pasteurization, and contains mainly lactic acid bacteria, i.e. useful microflora of the human body. Moreover, kvass contains natural organic acids, sugars and amino acids, which play an important role from the nutritional and physiological point of view. The primary metabolite of lactic acid bacteria, lactic acid, not only increase the bioavailability of calcium and other minerals, but also possesses an antioxidant properties. Products of yeast cells autolysis can enrich kvass environment with a 
number of valuable components, e.g. superoxide dismutase, able to "scavenge" excess of superoxide radicals (Dziugan, 2008).

Kvass as the beverage can be considered a probiotic, but it should be prepared by natural fermentation (not from concentrate) and with no further thermal stabilization (Kraszewska and Wzorek, 2006)

A perfect alternative for people with allergies to milk protein, who are forced to eliminate dairy products from diet, could be a grain products fermented with the participation of lactic acid bacteria. Such products are undoubtedly kvass and similar kind of drinks, like malt beverage (Kraszewska and Wzorek, 2006). The aim of this work was to produce kvass from mash obtained from commercial wholemeal rye bread, (manufactured by the traditional method), and to evaluate its quality in terms of consumer acceptance and chemical composition, including health promoting ingredients.

\section{MATERIAL AND METHODS}

For the production of kvass were used: "Lithuanian" wholemeal rye bread made in Krakow artisanal bakery according to traditional method, tap water, commercial pressed yeast, white sugar, raisins and barley malt (Department of Fermentation Technology and Technical Microbiology, University of Agriculture in Kraków), caramel (Wielkopolskie Przedsiębiorstwo Przemysłu Ziemniaczanego in Lubon) and citric acid.

The commercial bread kvasses included in the research material were as follows:

- Traditional taste (EKO - NATURA). Ingredients: treated water, extract of rye bread, sugar, yeast. Pasteurized

- Lithuanian Gubernija. Ingredients: rye bread rusks/biscuits $(2.2 \%)$, water, sugar, citric acid, $\mathrm{CO}_{2}$. Pasteurized, no preservatives.

- Kvass - ILGUCIEMA. Ingredients: water, sugar, rye - barley malt extract, acidity regulator, antioxidants: lactic acid, citric acid, $\mathrm{CO}_{2}$, yeast, ascorbic acid. Pasteurized

- Vilnius - Gerima Ingredients: rusk bread (2.5\%), rye and barley malt, water, sugar, $\mathrm{CO}_{2}$, lactic acid (acidity regulator). Pasteurized, no preservatives.

- Bogatyński. Ingredients: water, barley malt extract, natural flavour, natural wholemeal bread, sugar, cumin oil, natural colorant (caramel), acidity regulator (citric acid), $\mathrm{CO}_{2}$. Preserved with sodium benzoate.

\section{Methods}

Kvass was prepared according to the formula presented in the publication "The story of bread" by Piotr Kowalski, (Kowalski, 2007). Ingredients: $1 \mathrm{~kg}$ of dried wholemeal bread (rye, Lithuanian), 10 litres of tap water, $40 \mathrm{~g}$ yeast, $200 \mathrm{~g}$ sugar, $100 \mathrm{~g}$ raisins.

\section{Method of preparation}

$1 \mathrm{~kg}$ of bread (cut into small cubes and dried in air) was quenched with $3000 \mathrm{ml}$ water at a temperature of approximately $80^{\circ} \mathrm{C}$ was left for 30 minutes and occasionally stirred. After 30 minutes a further portion of water was added $(3000 \mathrm{ml})$ at a temperature of about $70^{\circ} \mathrm{C}$. Then, extraction was carried out for 1.5 hours with stirring at short intervals. The next step was a filtration of whole mash through cheesecloth, and adding a further portion of water $(3000 \mathrm{ml})$ at a temperature of about $70^{\circ} \mathrm{C}$. To the mash prepared in such way, $200 \mathrm{~g}$ of sugar dissolved in $1000 \mathrm{ml}$ of water, $40 \mathrm{~g}$ of yeast and $50 \mathrm{~g}$ raisins were added, and whole liquid was placed for 24 hours at $28^{\circ} \mathrm{C}$ for fermentation. After this time, kvass was separated from the sediment through a sieve lined with cotton gauze and the remaining $50 \mathrm{~g}$ of raisins was added. The whole amount of beverage was sweetened (about $100 \mathrm{~g}$ sugar for approximately 6 litres of kvass). Ready kvass was poured into a glass jars (1000 $\mathrm{ml}$ capacity), tightly capped and stored at refrigerator (approximately $8^{\circ} \mathrm{C}$ ) for a period of two weeks.

After storage kvass contained in all jars was subjected to centrifugation in a laboratory centrifuge MPW type $350(1250 \mathrm{x}$ g). To refine kvass, a laboratory made barley malt wort (Dziugan, 2008) was prepared. In order to obtain kvass with different flavours the following attempts of its refinement were performed (Table 1)

Table 1 Attempts of kvass refinement

\begin{tabular}{|c|c|c|c|c|c|}
\hline \multirow[b]{2}{*}{ Sample } & \multirow[b]{2}{*}{$\begin{array}{l}\text { Amount of mash } \\
{[\mathrm{ml}]}\end{array}$} & \multicolumn{4}{|c|}{ Addition } \\
\hline & & $\begin{array}{c}\text { Sugar } \\
{[\mathrm{g}]}\end{array}$ & $\begin{array}{c}\text { Citric acid } \\
{[\mathrm{g}]}\end{array}$ & $\begin{array}{c}\text { Malt wort } \\
{[\mathrm{ml}]}\end{array}$ & $\begin{array}{c}\text { Caramel } \\
{[\mathrm{ml}]}\end{array}$ \\
\hline 0 & 500 & 10 & 0 & 0 & 0 \\
\hline 1 & 500 & 10 & 0,2 & 0 & 0 \\
\hline 2 & 500 & 10 & 0 & 50 & 10 \\
\hline 3 & 500 & 10 & 0,2 & 50 & 10 \\
\hline 4 & 500 & 10 & 0 & 100 & 5 \\
\hline 5 & 500 & 10 & 0,2 & 100 & 5 \\
\hline 6 & 500 & 10 & 0,5 & 100 & 10 \\
\hline
\end{tabular}

Prepared in this manner, a six different samples of kvass were subjected to consumer evaluation test. After 7 days from refinement, kvass samples (No. 2 - 6) were subjected to organoleptic assessment in 5-point scale (Table 2). Also all commercial kvasses were evaluated. The following features were evaluated: colour, clarity, taste and intensity of sweet taste. The evaluation was carried out by 15 -person panel of proven sensory sensitivity.

\section{An attempts of kvass refinement after consumer evaluation}

Two top rated samples of kvass after the first refinement, i.e. No. 6 and 2, were subjected to further modification, taking into account consumers remarks. In this step, the number of samples was reduced from six to two, and they were refined in the following manner:

Modified sample No. 6 - $500 \mathrm{ml}$ mash, $100 \mathrm{ml}$ of malt wort, 10 $\mathrm{ml}$ of caramel, $7 \mathrm{~g}$ of sugar, $0.5 \mathrm{~g}$ of citric acid.
Modified sample No. 2 - $500 \mathrm{ml}$ mash, $50 \mathrm{ml}$ of malt wort, $5 \mathrm{ml}$ caramel, $7 \mathrm{~g}$ sugar.

Sample No. 1 was also modified (without the malt wort), adding a caramel and the increased amount of citric acid:

Modified sample No. $1-500 \mathrm{ml}$ mash, $2 \mathrm{ml}$ of caramel, $10 \mathrm{~g}$ of sugar, $0.7 \mathrm{~g}$ of citric acid

\section{Analytical methods}

Chemical analysis of manufactured and commercial kvasses: determination of acidity (PN - A - 74108, 1996); alcohol content (PN - 90 A - 75101/09, 1990); total protein by Kjeldahl method950.36, AOAC 2006); reducing sugars by Luff-Schoorl (PNA-74108, 1996); total dietary fibre (991.43, AOAC 2006); minerals with antioxidant properties (Copper and Zinc) - by flame atomic absorption spectrometry AAS (spectrometer Perkin Elmer ZL,USA).

The antioxidant activity was determined by FRAP method according to Benzie et al. (1996) including a modification by 
Bartoń et al. (2005), using a Multi-Mode Microplate Reader Synergy 2 Biotek Company (Biotek, USA).

Measurements for each sample were performed in triplicate, and as a result the average of three measurements \pm standard deviation (SD) was presented

\section{RESULTS AND DISCUSSION}

As was shown in the literature review, kvass is an excellent representative of a functional drinks group. However, in recent years it is produced from malt concentrate, since such technology enables the production on a large scale. Currently kvass based on traditional technology has completely disappeared from polish market (Dziugan, 2008)

In this work, the attempts to obtain the kvass by traditional method are presented. The basic raw material was air-dried rye bread, derived from artisanal bakery, manufactured by the classic 5-phase method. The use of commercial bread allowed to eliminate phase of wholemeal rye bread baking, which greatly simplified the production process, and can act as an encouragement for the production of such a beverage at home. In a first sample, noted in this work as No. 0, kvass was produced exclusively from bread and sugar (sucrose) extract. The resulting drink was characterized by too little acidity (organoleptically assessed), unsatisfactory colour (too bright) and low clarity. Its appearance and taste significantly differ from the commercial kvasses, although it was the most natural product.

Therefore, in the second sample, acidity of beverage was increased by adding a citric acid. This sample was labelled as number 1.
Trying to improve colour and taste of kvass (make them similar to commercial kvasses) wort was prepared from barley malt, which was added to another sample (No. 2), as well as an addition of caramel was introduced, as proposed by Dziugan (2008). The resulting kvass was characterized by a much better flavour and colour, as compared to the sample No. 1, but as previously too little acidic. So, to the next sample a more citric acid was added, and it was marked as No. 3 .

In two subsequent samples, numbered as 4 and 5, pursuing to an even greater refinement of kvass, an amount of malt wort was increased two times, and the content of caramel was reduced two times. Sample No. 5 was different from the sample No. 4 only by the addition of citric acid.

In the last sample, indicated as No. 6, an increased content of the wort (as in samples No 4 and 5), but the initial amount of caramel $(10 \mathrm{ml})$ was applied, as in sample No. 2 and 3, and increased more than two times the addition of citric acid.

Kvass samples 2 - 6 and commercial kvasses were subjected to an organoleptic evaluation, and the following indicators were evaluated: taste, colour, clarity and intensity of sweet taste. The results of this evaluation are provided in Table 3 .

Among the own produced kvasses, the most points for all evaluated indicators, mainly for flavour, collected kvass No. 6 , yielding 4 points from a 5 possible. Among the commercial kvasses the highest consumer acceptance was granted to kvass "Kwass - Ilguciema", earning 4.2 points out of 5 possible. This kvass was produced from rye-barley malt extract with addition of antioxidants (citric and lactic acids), and with the addition of $\mathrm{CO}_{2}$, it was also pasteurized. Addition of $\mathrm{CO}_{2}$ indicates, that during its production there was no natural fermentation, as it took place during laboratory scale production.

Table 3 The results of organoleptic assessment of commercial and own produced kvasses

Wn produced kvasses

(No.)

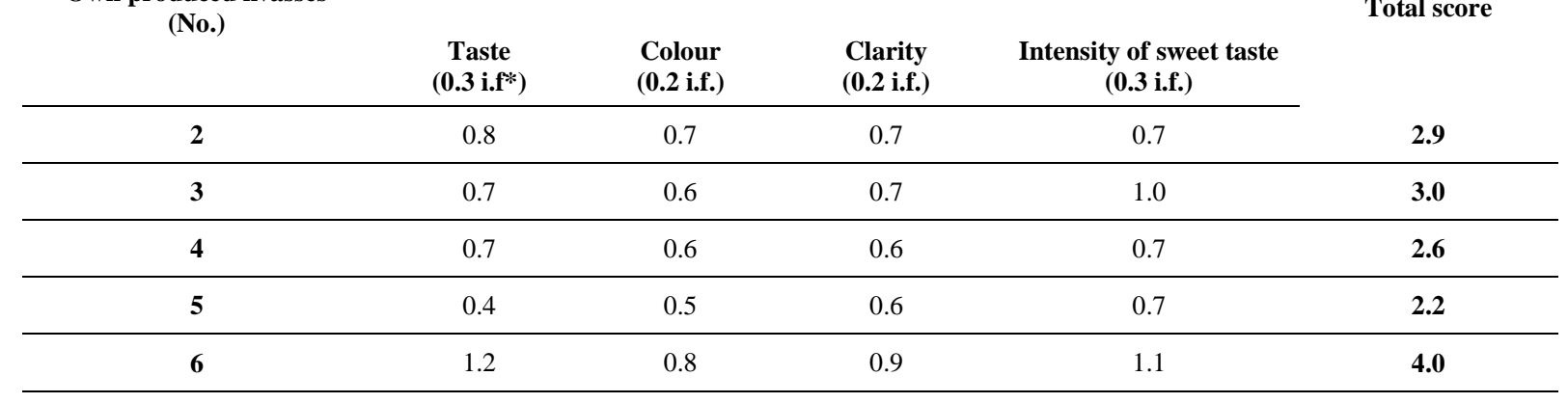

Commercial kvasses

\begin{tabular}{cccccc} 
Eko - Natura & 0.9 & 0.4 & 0.6 & 0.7 & 1.0 \\
\hline Litewski Gubernija & 0.9 & 0.7 & 0.8 & 1.2 & $\mathbf{3 . 4}$ \\
\hline Kwass - Ilguciema & 1.2 & 0.9 & 0.9 & 1.0 & $\mathbf{4 . 2}$ \\
\hline Wileński - Gerima & 1.0 & 0.8 & 0.8 & 0.9 & $\mathbf{3 . 0}$ \\
\hline Bogatyński & 0.6 & 0.7 & 0.8 & \\
\hline rimportance factor & & &
\end{tabular}

Based on the results of the organoleptic evaluation, the second mash was prepared from bread and water, and the same additives were used as in the evaluated samples No. 6 and 2, but slight modification was introduced. Namely: sugar content in both samples was reduced (as a benefit for consumers health) from 10 $\mathrm{g}$ to $7 \mathrm{~g} / 500 \mathrm{ml}$ of mash, and in sample No. 2 the amount of caramel was reduced from $10 \mathrm{ml}$ to $5 \mathrm{ml} / 500 \mathrm{ml}$ of mash. These refined samples were subjected to chemical composition analysis.

The content of chemical components was also determined in samples of kvass with the most natural composition, both from own production as well as commercial. It was sample No. 1 (without addition of malt wort), which however was slightly modified, namely the addition of citric acid was increased more than threefold (from $0.2 \mathrm{~g}$ to $0.7 \mathrm{~g} / 500 \mathrm{ml}$ of mash) and a small amount of caramel was added $-2 \mathrm{ml} / 500 \mathrm{ml}$ mash.

Among the commercial kvasses EKO - NATURA was selected, because according to its specifications it was produced from the extract of rye bread (not from concentrate malt), without the addition of antioxidants and $\mathrm{CO}_{2}$.

The results of the basic chemical composition analysis of kvasses are summarized in Table 4. 
Table 2 Criteria for kvass sensory assessing/evaluation (own study/elaboration)

\begin{tabular}{|c|c|c|c|c|c|}
\hline \multirow{2}{*}{ Quality -indicators } & \multicolumn{5}{|c|}{ Amounts of points } \\
\hline & 5 & 4 & 3 & 2 & 1 \\
\hline Taste (i.f. $=0.3$ ) & $\begin{array}{l}\text { Highly harmonized, sweet - sour, } \\
\text { very characteristic for flavoring } \\
\text { substances used, highly pure }\end{array}$ & $\begin{array}{l}\text { Harmonized, sweet - sour, } \\
\text { characteristic for flavoring } \\
\text { substances used, pure }\end{array}$ & $\begin{array}{l}\text { Less harmonized, slightly bitter } \\
\text { or too astringent, less } \\
\text { characteristic for flavoring } \\
\text { substances used, less clear }\end{array}$ & $\begin{array}{c}\text { Not harmonized too sour or too } \\
\text { sweet, less characteristic for } \\
\text { flavoring substances used, not } \\
\text { clear } \\
\end{array}$ & $\begin{array}{l}\text { Very weak or no taste at all, } \\
\text { foreign taste, clearly changed }\end{array}$ \\
\hline Colour (i.f. $=0.2$ ) & $\begin{array}{l}\text { Very uniform and homogenous, } \\
\text { from light brown to dark brown, } \\
\text { very characteristic for the } \\
\text { additives used, highly specific, } \\
\text { intense. }\end{array}$ & $\begin{array}{l}\text { Uniform, homogenous, from } \\
\text { light brown to dark brown, } \\
\text { characteristic for the additives } \\
\text { used, specific, intense. }\end{array}$ & $\begin{array}{c}\text { Slightly less uniform and } \\
\text { homogenous, from light brown } \\
\text { to dark brown, slightly less } \\
\text { characteristic for the additives } \\
\text { used, specific }\end{array}$ & $\begin{array}{l}\text { Less intense, slightly less } \\
\text { uniform and homogenous, from } \\
\text { light brown to dark brown, not } \\
\text { too characteristic for the } \\
\text { additives used, not too proper }\end{array}$ & $\begin{array}{l}\text { Not uniform, not homogenous, } \\
\text { less or not characteristic for } \\
\text { additives used, not proper at all }\end{array}$ \\
\hline Clarity (i.f. $=0.2$ ) & $\begin{array}{l}\text { Highly clear and uniform, } \\
\text { slightly cloudy. }\end{array}$ & $\begin{array}{c}\text { Clear and uniform, slightly } \\
\text { cloudy. }\end{array}$ & Clear, fairly uniform, cloudy & $\begin{array}{l}\text { Less clear, not uniform, fairly } \\
\text { cloudy }\end{array}$ & Not uniform, not clear, cloudy \\
\hline $\begin{array}{c}\text { Intensity of sweet taste (i.f. }= \\
0.3 \text { ) }\end{array}$ & $\begin{array}{l}\text { Very well perceptible, very } \\
\text { intense. }\end{array}$ & Well perceptible, intense. & $\begin{array}{l}\text { On average perceptible, slightly } \\
\text { less intense }\end{array}$ & $\begin{array}{l}\text { Very weak perceptible, less } \\
\text { intense }\end{array}$ & $\begin{array}{c}\text { Very little intense, very weak } \\
\text { perceptible or not perceptible at } \\
\text { all }\end{array}$ \\
\hline
\end{tabular}

i.f. - importance factor 
Table 4 Chemical composition of consumer chosen own made and commercial kvasses

\begin{tabular}{|c|c|c|c|c|c|}
\hline Kind of kvass & $\begin{array}{c}\text { Acidity } \\
{\left[{ }^{\circ}\right]}\end{array}$ & $\begin{array}{l}\text { Alcohol content } \\
\text { [\% vol.] }\end{array}$ & $\begin{array}{c}\text { Protein content } \\
{[\% \mathbf{d m}]}\end{array}$ & $\begin{array}{c}\text { Sugars content } \\
\text { [g/100 ml of kvass] }\end{array}$ & $\begin{array}{c}\text { Dietary fibre } \\
\text { content } \\
\text { [g/100 ml of kvass] }\end{array}$ \\
\hline $\begin{array}{c}\text { Modified sample } \\
\text { No } 6 \\
\end{array}$ & 4.2 & 0.34 & 0.13 & 4.5 & 0.3 \\
\hline $\begin{array}{c}\text { Modified sample } \\
\text { No } 2\end{array}$ & 3.0 & 0.34 & 0.12 & 4.1 & 0.4 \\
\hline $\begin{array}{c}\text { Modified sample } \\
\text { No } 1 \\
\end{array}$ & 4.4 & 0.34 & 0.12 & 4.6 & 0.5 \\
\hline $\begin{array}{c}\text { Eko-Natura } \\
\text { kvass }\end{array}$ & 2.6 & 0.00 & 0.1 & 4.2 & 0.2 \\
\hline $\begin{array}{c}\text { Kwass - Ilguciema } \\
\text { kvass }\end{array}$ & 3.6 & 0.00 & 0.3 & 12.0 & 0.1 \\
\hline
\end{tabular}

Kvasses with no citric acid addition were characterized by the lowest acidity (No. 2 and EKO - NATURA), and the greatest was detected in modified kvass No. 1, with the highest level of added citric acid.

Own made kvasses were characterized by a minimum alcohol content, equal in all samples, which resulted from the natural alcohol - lactic acid fermentation. This determined amount of alcohol does not exceed the permissible content of $0.5 \%$ vol., which determines the acceptation of such drinks as a soft drinks (Czerwińska, 2008; Dziugan, 2008). Commercial kvasses contain no alcohol, which in the case of ILGUCIEMA is proof for the lack of natural fermentation, while in the case of EKO - NATURA, as can be assumed, could be due to too small addition of yeast, that can be confirmed by a lack of natural $\mathrm{CO}_{2}$ content in this kvass. That was observed in kvasses from own production, where the presence of gas was organoleptically detectible.

All kvasses produced from bread mash i.e. own production and EKO - NATURA were characterized by comparable protein content, unlike ILGUCIEMA kvass, where the highest content of this compound was detected. This protein is likely to come from rye - barley malt extract, where protein was denatured to a significantly less extent, as compared to the bread, which is subjected to high temperatures during the baking process.

ILGUCIEMA kvass was also distinguished by approximately 3 - fold higher content of reducing sugars in relation to other kvasses, which in times of increased incidence of diabetes was rather an unfavorable result (Kolanowski, 2005; Czerwińska, 2008). Other kvasses produced by natural fermentation, contained very similar and low level of sugars, which in accordance with literature reports can be utilized in ailments related to diabetes, atherosclerosis and asthma (Kolanowski, 2005).

The kvasses produced from a mash made from rye bread, i.e. own produced and EKO - NATURA, were characterized by a higher content of fibre than in ILGUCIEMA kvass, especially in own produced kvasses made from wholemeal rye bread, containing more fibre than white bread (Gasiorowski, 1994; Moscick and Wojtowicz, 2009). As known from previous studies (Kolanowski, 2005; Dziugan, 2008), a health promoting compounds like: vitamins, especially from B group (present in rye flour and generated by yeast), minerals as well as live lactic acid bacteria (if kvass was not pasteurized) could be transferred from rye bread into kvass.

Increased antioxidant activity was determined in the own produced kvass without any additives (No. 0), in comparison to the EKO - NATURA kvass (Table 5), indicated on a higher content of lactic acid bacteria and lactic acid in own produced kvass, because in its preparation a wholemeal rye bread was used, not rye bread, as declared on the label of EKO - NATURA.

However, the two kvasses mentioned above were characterized by a much lower antioxidant activity where compared to kvasses supplemented with caramel (Table 5 - samples No. 2 - 6). The caramel contains Maillard reaction products, which are also included in the compounds with antioxidant properties (Eichner, 1981; Morales et al., 2009). The greater caramel addition, the more increase of antioxidant activity was observed in the investigated own produced kvasses samples No. 2, 3 and 6 (Table 5). The antioxidant activity of the investigated kvasses, especially own manufactured, but also in the commercial ones, was influenced by addition of the antioxidant compound like citric acid. In the self produced kvass No. 6 , where the highest amount of citric acid was added, the highest antioxidant activity was determined. Among the commercial kvasses the highest antioxidant activity was measured in ILGUCIEMA kvass, which (according to the recipe on the label) was produced with addition of lactic and citric acids.

Table 5 summarizes the results of determinations of zinc and copper, as the trace elements which stimulate the action of antioxidant enzymes in the human body, and act as a natural defence system against reactive oxygen species (ROS) or free radicals. Therefore, they can be assumed as antioxidants (Zieliński and Kozłowska, 2000; Zielinski et al. 2001 a, b; Zielinski 2002; Edge et al., 2005), which the normal levels in the body ensures high antioxidant enzyme activity. Copper content in the investigated kvasses was too low for determination, the highest zinc content was determined in the commercial Gubernija lithuanian acid (Table 5), but on other hand it did not receive a high consumer acceptance (Table 3 ). In the best organoleptically assessed self produced kvass No. 6 the significantly higher content of zinc was detected, regardless of the additives used. In all kvasses the content of this component was negligible, and therefore no nutritional importance can be ascribed.

It should be concluded, that the most important aspect during manufacturing of kvass is application of natural fermentation, and in this way the characteristics for this beverage taste and health benefits are achieved. Kvass may become an alternative to soft drinks (e.g. Cola), which are very popular, but are not characterized by any health benefits. This drink, produced by the traditional method, can become a very attractive commodity on the market of the European Union, where health awareness is at a high level, and a search for natural healthy and tasty with functional properties products is ongoing.

Unfortunately, these values were not detected in the investigated in our study drinks present on the polish market sold under the name "Kvass".

\section{CONCLUSIONS}

It is possible to produce a good quality kvass based on wholemeal rye bread, baked by traditional, 5-phase method, similar in organoleptic qualities to commercial kvasses, where numerous flavours and preservatives are used. Natural kvass can be used by consumers of all ages, since it contained only trace amount of alcohol, and the dietary fibre content is approximately twice higher when compared to commercial ones. Laboratory manufactured kvasses from wholemeal rye bread revealed a $60 \%$ increase in antioxidant activity when compared to commercial kvasses. The increased antioxidant activity of laboratory manufactured kvass was influenced not by addition of barley malt wort, but by addition of caramel and citric acid. Kvasses produced by natural alcohol - lactic acid fermentation contained comparable, small amount of reducing sugars, a 3 times lower when compared to commercial kvasses. The content of zinc and copper - elements of an antioxidant, in all tested kvasses was too small to play the role in health prevention. Using a proven recipe it is possible to manufacture kvass at home, and store it in the refrigerator for several weeks. 
Table 5 Antioxidant activity and mineral compounds with antioxidant capacity content in self-made and commercial kvasses

\begin{tabular}{|c|c|c|c|c|}
\hline \multirow{2}{*}{ Self-made kvasses } & \multicolumn{2}{|c|}{ FRAP $(\mu M / L)$} & \multicolumn{2}{|c|}{$\mathrm{Zn}$ content $[\mathrm{mg} \mathbf{Z n} / \mathrm{L}]$} \\
\hline & \multicolumn{2}{|c|}{ Average \pm SD } & \multicolumn{2}{|c|}{ Average \pm SD } \\
\hline $\mathbf{0}$ & 513,7 & 15,9 & 0,042 & 0,003 \\
\hline 1 & 737,1 & 15,9 & 0,042 & 0,003 \\
\hline 2 & 1771,4 & 53,5 & 0,078 & 0,007 \\
\hline 3 & 1955,1 & 85,0 & 0,129 & 0,004 \\
\hline 4 & 404,3 & 11,6 & 0,085 & 0,003 \\
\hline 5 & 945,3 & 31,7 & 0,210 & 0,007 \\
\hline 6 & 2620,7 & 63,1 & 0,188 & 0,005 \\
\hline \multicolumn{5}{|l|}{ Commercial kvasses } \\
\hline EKO-NATURA & 442,6 & 11,6 & 0,131 & 0,003 \\
\hline Gubernija & 807,7 & 25,5 & 0,407 & 0,011 \\
\hline Ilguciema & 1556,1 & 19,7 & 0,049 & 0,009 \\
\hline Gerima & 726,1 & 23,5 & 0,049 & 0,004 \\
\hline Bogatyński & 93,4 & 6,0 & 0,000 & 0,002 \\
\hline
\end{tabular}

\section{REFERENCES}

AOAC. 2006 - Official methods of analysis, $18^{\text {th }}$ edn. Gaithersburg Association of Official Analytical Chemists International.

BARTOŃ, H., FOLTA, M., ZACHWIEJA, Z. 2005. Application of FRAP, ABTS and DPPH methods to estimation of antioxidant activity of food products (in Polish, English abstract), Nowiny Lekarskie, 74, 510 - 513.

BENZIE, I.F.F., STRAIN, J.J. 1996. The ferric reducing ability of plasma (FRAP) as a measure of antioxidant power: The FRAP Assay. Anal. Biochem $239,70-76$.

CZERWIŃSKA D. 2008. Czas na kwas. Przeglad Gastronomiczny, 71, 9, 9 - 10. DZIUGAN P. 2006 a. Kwas chlebowy - napój na nowo odkrywany (1). Przemyst Fermentacyjny i Owocowo - Warzywny, 50, 6, 21 - 22.

DZIUGAN P. 2006 b. Kwas chlebowy - napój na nowo odkrywany (2). Przemyst Fermentacyjny i Owocowo - Warzywny, 50, 7 - 8, 74 - 76.

DZIUGAN P. 2008. Kwas chlebowy zdrowy i orzeźwiający. Przegląd Piekarski $i$ Cukierniczy, 56, 6, 58 - 62.

EDGE, M.S., JONES, J.M., MARQUART, L. 2005. A new life for whole grains. J. Am. Diet. Assoc., 15, 12, 1856 - 1860.

EICHNER, K., 1981. Antioxidative effect of Maillard reaction intermediates. Progr. Food Nutr. Sci.5, 441-451.

KOLANOWSKI, W.. 2004. Kwas chlebowy - zdrowe orzeźwienie. Przeglad Gastronomiczny, 58, 7 - 8, 14 .

KOWALSKI, P.. 2007. Opowieść o chlebie czyli nasz powszedni. Wyd. IKON Kraków.

KRASZEWSKA, J., WZOREK W.. 2006. Probiotyki a żywność pochodzenia roślinnego. Przemyst Spożywczy, 60, 6, 32 - 34.

MORALES, F.J., MARTIN, S., ACAR, Ö.Ç., ARRIBAS-LORENZO,G., GOKMEN, V.. 2009. Antioxidant activity of cookies and its relationship with heat-processing contaminants: a risk/benefit approach. Eur. Food Res. Technol., 3 (228), 345-354.

MOŚCICKI, L., WÓJTOWICZ, A. 2009. Produkty pełnoziarniste Część III. Błonnik. Przeglad Zbożowo - Młynarski, 53, 5, 7 - 11.

PN-9 A-75101/09.. 1990. Przetwory owocowe i warzywne. Przygotowanie próbek i metody badań fizykochemicznych. Wyd. Normalizacyjne, Warszawa. PN-A-74108. 1996. Pieczywo. Metody badań.

ZIELIŃSKI, H., CISKA, E., KOZŁOWSKA, H. 2001 a. The cereal grains: Focus on vitamin E. Czech Journal of Food Sciences, 5, 182 - 188.
ZIELIŃSKI, H., KOZŁOWSKA, H., LEWCZUK, B. 2001b. Bioactive compounds in de cereal grains before and after hydrothermal processing. Innovative Food Science and Emerging Technologies, 2, 159 - 169.

ZIELIŃSKI, H., KOZŁOWSKA H. 2000. Antioxidant activity and total phenolics in selected cereal grains and their different morphological fractions. Journal of Agricultural and Food Chemistry 48, 2008 - 2016. 